\title{
L- and T-Type Calcium Channels in Acutely Isolated Neonatal and Adult Cardiac Myocytes
}

\author{
GLENN T. WETZEL, FUHUA CHEN, AND THOMAS S. KLITZNER
}

Department of Pediatrics, Division of Cardiology, University of California at Los Angeles, Los Angeles, California 90024

\begin{abstract}
We have compared transsarcolemmal $\mathrm{Ca}^{2+}$ currents in acutely isolated neonatal (1- to 5-d-old) and adult rabbit cardiac myocytes prepared using similar enzymatic techniques. Time- and voltage-dependent inward $\mathrm{Ca}^{2+}$ currents were measured using the whole-cell voltage clamp technique. In neonatal myocytes, peak $\mathrm{Ca}^{2+}$ currents measured $114 \pm 10 \mathrm{pA}$ (mean $\pm \mathrm{SEM}, n=18$ ) as compared with $2014 \pm 403 \mathrm{pA}$ in adult myocytes $(n=5, p<0.001)$. Although adult myocytes had a larger surface area (estimated from cell capacitance) than neonatal cells $(113 \pm 15$ $\times 10^{-6}$ versus $28 \pm 2 \times 10^{-6} \mathrm{~cm}^{2}, p<0.001$ ), the calculated peak current density was also significantly larger in adult cells $\left(17.9 \pm 2.5\right.$ compared to $4.3 \pm 0.4 \mu \mathrm{A} / \mathrm{cm}^{2}$ for neonatal cells, $p<0.001$ ). The voltage dependence of the peak $\mathrm{Ca}^{2+}$ current was similar in neonatal and adult myocytes. Early transient (T-type) $\mathrm{Ca}^{2+}$ currents were also studied by comparing the current induced by depolarization to $-20 \mathrm{mV}$ from holding potentials of -40 and $-80 \mathrm{mV}$. T-type $\mathrm{Ca}^{2+}$ channels were present in $91 \%$ of the adult cells but were evident in only $39 \%$ of the neonatal cells. In summary, voltage-gated $\mathrm{Ca}^{2+}$ current amplitude, current density, and T-type $\mathrm{Ca}^{2+}$ channel prevalence all increase with maturation. These data suggest that neonatal myocytes may be relatively deficient in $\mathrm{Ca}^{2+}$ channel activity when compared to adult myocytes. (Pediatr Res 30: 89-94, 1991)
\end{abstract}

\section{Abbreviations}

HEPES, $N$-2-hydroxyethylpiperazine- $N^{\prime}$-2-ethanesulfonic acid

Time- and voltage-dependent transsarcolemmal Ca ${ }^{2+}$ currents have been described in preparations of cardiac papillary muscle and single cardiac myocytes from various mammalian species (1-6). Investigators using whole-cell voltage clamp and patch clamp techniques have directly measured $\mathrm{Ca}^{2+}$ channel characteristics in isolated adult myocytes $(1,3)$. Other studies have demonstrated the presence of at least two distinct types of $\mathrm{Ca}^{2+}$ channels in mature myocardium, one termed L (long lasting) and the other $\mathrm{T}$ (transient) $(4,6)$. However, the exact role of these currents in the development of tension or the generation of the action potential has not been elucidated. It has been suggested that $\mathrm{L}$ channels may replenish intracellular $\mathrm{Ca}^{2+}$ pools, whereas $T$ channels may play a role in triggering the release of $\mathrm{Ca}^{2+}$ stored in the sarcoplasmic reticulum $(5,7)$.

Received August 31, 1990; accepted February 28, 1991.

Correspondence and reprint requests: Thomas Klitzner, M.D., Ph.D., Department of Pediatrics, UCLA School of Medicine, Los Angeles, CA 90024.

Supported in part by funding from the NIH (HL-01347 and HL-035783), the American Heart Association, Greater Los Angeles Affiliate (829 GI, 788 IG) and the Variety Club, J. H. Nicholson Endowment. T.S.K. is currently a Senior Investigator of the American Heart Association, Greater Los Angeles Affiliate.
In mature myocardium, the depolarization-induced rise in intracellular $\mathrm{Ca}^{2+}$ responsible for tension generation is largely the result of release of $\mathrm{Ca}^{2+}$ from the sarcoplasmic reticulum $(5,7)$. In contrast, immature myocardium is deficient in $T$ tubules and sarcoplasmic reticulum and is relatively more dependent on transsarcolemmal $\mathrm{Ca}^{2+}$ influx to initiate tension development $(2$, 8-13). However, there are few reports describing sarcolemmal $\mathrm{Ca}^{2+}$ channels in immature mammalian heart cells (14-17). We have studied the voltage dependence and magnitude of $\mathrm{Ca}^{2+}$ currents in neonatal and adult rabbit cardiac myocytes isolated by similar enzymatic techniques.

\section{MATERIALS AND METHODS}

Cell isolation. Cardiac myocytes from neonatal (1- to 5-d-old, $50-$ to $100-\mathrm{g}$ ) and adult (1.5- to $2.5-\mathrm{kg}$ ) New Zealand White rabbits were prepared by enzymatic dissociation as previously described $(13,16)$. Briefly, the intact heart was dissected from anaesthetized, heparinized rabbits and perfused via an aortic cannula with warmed $\left(37^{\circ} \mathrm{C}\right) 0 \mathrm{mM} \mathrm{Ca}{ }^{2+}$ Tyrode's solution for 3 min (flow rate $=2.5 \mathrm{~mL} / \mathrm{min}$ for neonates, flow rate $=45 \mathrm{~mL}$ / min for adults, solution composition with concentrations expressed in mM: $\mathrm{NaCl} 136, \mathrm{KCl} 5.4, \mathrm{NaH}_{2} \mathrm{PO}_{4} 0.33, \mathrm{MgCl}_{2}$, HEPES 10 , mannitol 4, thiamine $\mathrm{HCl} 0.6$, glucose 10 , pyruvic acid $2, \mathrm{pH} 7.35$ ). The perfusing solution was then changed to include collagenase $(300 \mathrm{U} / \mathrm{mL}$, Type I; Sigma Chemical Co., St. Louis, MO) and protease $(0.35 \mathrm{U} / \mathrm{mL}$, Type XIV; Sigma). Perfusion time varied from 7 to 9 min for neonatal hearts and 50 to $70 \mathrm{~min}$ for adult hearts. The enzyme solution was removed by perfusion with $0.1 \mathrm{mM} \mathrm{Ca}{ }^{2+}$ Tyrode's solution for $3 \mathrm{~min}$. The intact ventricles were opened and shaken in a petri dish to disperse isolated myocytes.

Experimental preparation. Isolated cells were placed in a $1-$ $\mathrm{mL}$ experimental chamber on the stage of an inverted microscope (Nikon Diaphot, Garden City, NY) (temperature $23-24^{\circ} \mathrm{C}$ ). Microelectrodes were pulled from Corning 7052 or 8161 glass capillary tubing (Corning, Horsehead, NY). Pipettes used for neonatal cells had a tip resistance of 4 to 8 (typically 5) $\mathrm{M} \Omega$ when measured in Tyrode's solution. Pipettes used for adult cells had a tip resistance of 2 to 5 (typically 4 ) $\mathrm{M} \Omega$. Cells were voltage clamped in the whole-cell configuration using an EPC-7 patch clamp amplifier (Adams/List, Great Neck, NY) (18). Series resistance averaged $14 \pm 1 \mathrm{M} \Omega(n=51)$ in neonates (16). Series resistance compensation $(78-90 \%)$ with paraffin coated pipettes was used for adult cells, resulting in a decrease in mean series resistance from $13 \pm 2 \mathrm{M} \Omega$ to $1.8 \pm 0.6 \mathrm{M} \Omega(n=5)$. The resistance of the pipettes used for neonatal cells was higher than is commonly described (18). However, due to the small size of the cells (mean capacitance was less than $30 \mathrm{pF}$ ) and small amplitude of the recorded currents (less than $300 \mathrm{pA}$ ) voltage clamp control was achieved without series resistance compensation. The interior of the cell was dialyzed with internal pipette solution via the open pipette tip, allowing experimental control of the interior ionic composition of the cell (16). The current 
signal was filtered at $1 \mathrm{kHz}$ using an eight-pole Bessel filter (Frequency Devices, Haverhill, MA). Microelectrode offset potentials were compensated before approaching the cell membrane.

Membrane potential and current were recorded on a dualbeam storage oscilloscope and photographed for later analysis or stored in digital form (Axolab 1100 data acquisition system and pCLAMP software; Axon Instruments, Inc., Foster City, CA) on the hard disk of a microcomputer (IBM AT). Series resistance was measured using the transient cancellation circuitry of the patch clamp amplifier (19).

The capacitance of the cells was determined by measuring the steady state current required to hyperpolarize the cell membrane at a steady rate $(5 \mathrm{mV} / 5 \mathrm{~ms})$. During capacitive measurements, the contribution of time- and voltage-dependent currents was minimized by using brief, small voltage changes. Cell surface area was calculated by multiplying cell capacitance by $1 \times 10^{-6}$ $\mathrm{cm}^{2} / \mathrm{pF}(20)$. Cell capacitance for neonatal cells using this technique was similar to that found using the transient compensation method (16).

Measurement of $\mathrm{Ca}^{2+}$ currents. After an initial 5-min equilibration period to allow for cell dialysis with pipette solution, $\mathrm{Ca}^{2+}$ currents were recorded during sequential voltage clamp steps from a holding potential of -40 or $-80 \mathrm{mV}$. Depolarizations lasting 100 or $400 \mathrm{~ms}$ were performed at 5-s intervals to test potentials between -40 and $60 \mathrm{mV}$ in $10-\mathrm{mV}$ increments. Peak $\mathrm{Ca}^{2+}$ current was unaffected by the duration of the depolarization. The pipette (internal) solution contained (in $\mathrm{mM}$ ): $\mathrm{CsCl}$ 96, HEPES 20, EGTA 14, $\mathrm{CaCl}_{2} 1, \mathrm{MgCl}_{2} 1$, ATP-Mg 5 , titrated to $\mathrm{pH} 7.1$ with $\mathrm{CsOH}$. The bath (external) solution contained (in mM): $\mathrm{CsCl} 135$, HEPES $10, \mathrm{CaCl}_{2} 10, \mathrm{MgCl}_{2} 1$, glucose 10, tetrodotoxin (Sigma) 0.01, titrated to pH 7.3 with $\mathrm{CsOH} . \mathrm{Cs}^{+}$and tetrodotoxin were included to block $\mathrm{K}^{+}$and $\mathrm{Na}^{+}$ channels, respectively. A small linear "leak" current was subtracted from current recordings based on the cell resistance (approximately $10 \mathrm{G} \Omega$ with 8161 glass capillary pipettes). T-type $\mathrm{Ca}^{2+}$ currents were identified by the presence of an early, transient inward current present upon depolarization from $-80 \mathrm{mV}$ to test potentials in the range -30 to $-10 \mathrm{mV}$ but absent during similar depolarizations from a holding potential of $-40 \mathrm{mV}$.

Statistical analysis. Measured values are reported as mean \pm SEM and analyzed by $t$ test unless otherwise indicated.

\section{RESULTS}

L-type $\mathrm{Ca}^{2+}$ currents. Depolarization of isolated cardiac myocytes in $10 \mathrm{mM} \mathrm{Ca}^{2+}$ solution induced time- and voltagedependent $\mathrm{Ca}^{2+}$ currents. Original records from representative neonatal and adult myocytes are shown in Figure 1. Currents displayed a similar time course in the two age groups, peaking 10 to $15 \mathrm{~ms}$ after initiation of the clamp step and largely inactivating within $100 \mathrm{~ms}$. This time course is similar to that described for $L$ currents in other preparations $(3,4,15,17)$. As may be seen from comparing Figures $1 A$ and $B$, however, the peak current in adult myocytes was much larger than that recorded in neonatal cells.

The larger magnitude of the $\mathrm{Ca}^{2+}$ current in adult cells is in part a reflection of their larger size. As shown in Figure $2 A$, the mean surface area of adult cells was four times that of neonatal cells $\left(113 \pm 15 \times 10^{-6} \mathrm{~cm}^{2}, n=5\right.$, versus $28.0 \pm 1.9 \times 10^{-6} \mathrm{~cm}^{2}$, $n=18, p<0.001)$. As indicated in Figure 1, the peak current in the mature cells was larger than in neonatal cells $(2014 \pm 400$ versus $114 \pm 10 \mathrm{pA}, p<0.001$ ) (Fig. $2 B$ ). Importantly, however, when peak current was normalized to surface area, the current density of adult myocytes was significantly larger than that of neonatal cells $\left(17.9 \pm 2.5\right.$ versus $\left.4.3 \pm 0.4 \mu \mathrm{A} / \mathrm{cm}^{2}, p<0.001\right)$ (Fig. 2C).

The relation between peak current and membrane potential was similar in neonatal and adult cells (Fig. 3). The average test potential at which the largest inward current occurred was $7 \pm 2$

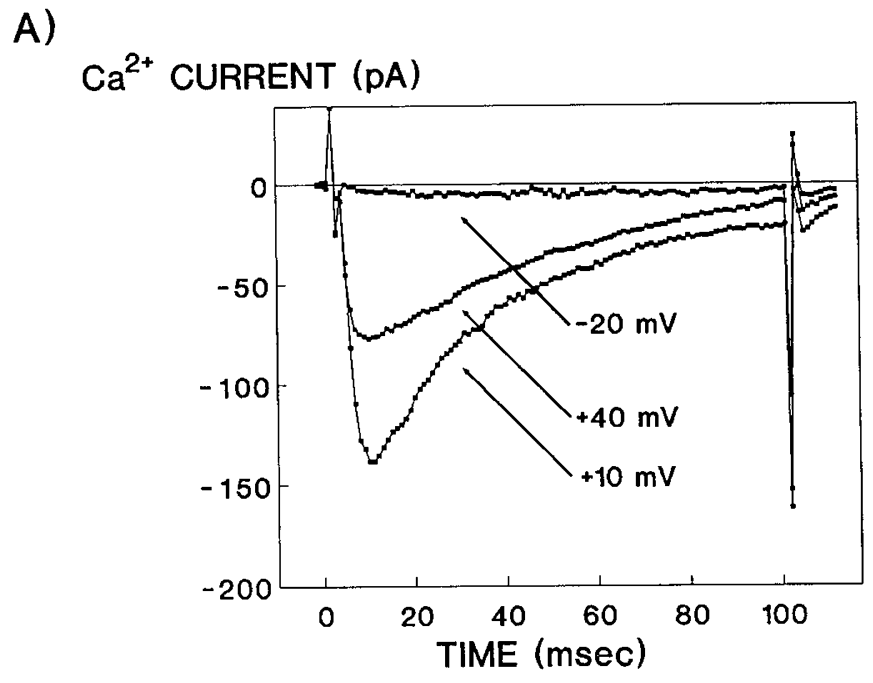

B)

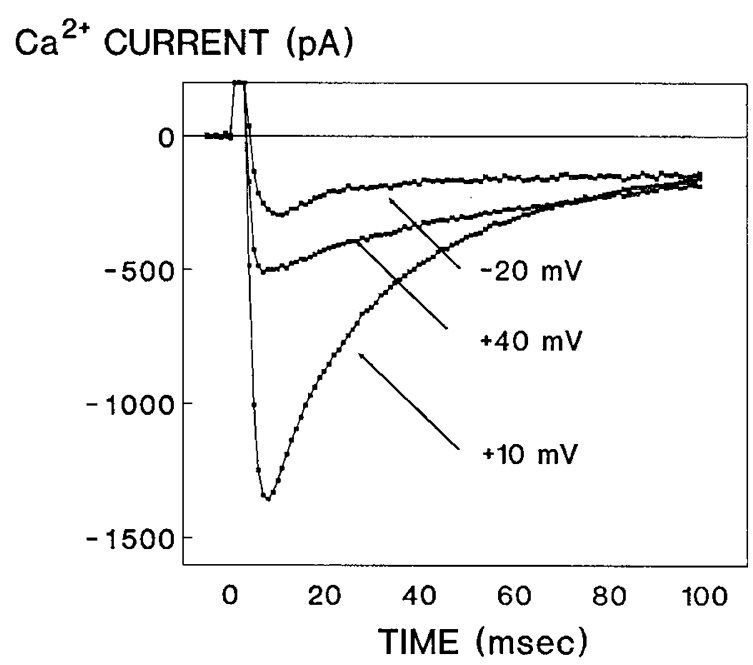

Fig. 1. Voltage-dependent $\mathrm{Ca}^{2+}$ currents. Current records as a function of time are shown during membrane potential steps to $-20,10$, and $40 \mathrm{mV}$ from a holding potential of $-80 \mathrm{mV}$ (traces are shown after subtraction of a small linear leak current). $\mathrm{Ca}^{2+}$ concentration in the bath solution is $10 \mathrm{mM} . \mathrm{Cs}^{+}$replaced $\mathrm{K}^{+}$in the bath and internal electrode solutions to block current through $\mathrm{K}^{+}$channels. The bath also contained $10 \mu \mathrm{M}$ tetrodotoxin to block $\mathrm{Na}^{+}$channels. The traces represent original data stored in digital form at $1 \mathrm{kHz}$. Inward current is displayed as downward (negative) deflections from the zero current level as indicated. $A$, Current recorded from a myocyte isolated from a 3-d-old rabbit during a $100-\mathrm{ms}$ depolarization. The depolarization to $-20 \mathrm{mV}$ produces a brief (2- to 5-ms) capacitive spike but little inward current. At higher potentials, an inward current rapidly activates and then gradually inactivates over the course of a 100-ms voltage step. Cell no. 89913B. B, Current recorded from a myocyte isolated from an adult rabbit. Although the magnitude of the peak inward current is much larger in the mature cell (note the difference in scaling of the current), the voltage dependence of activation and inactivation appears qualitatively similar to that seen in the neonatal cell. However, a large, sustained inward current is apparent in the tracings from the adult cell that is not present in the neonatal cell tracing. To simplify comparison with currents from the neonatal cell, only data from the first $100 \mathrm{~ms}$ of a $400-\mathrm{ms}$ depolarization is shown. Cell no. 90405A.

$\mathrm{mV}$ in neonatal myocytes and $8 \pm 2 \mathrm{mV}$ in adult myocytes. Thus, it appears that the increase in peak current density with development is not related to a change in the voltage dependence of steady state $\mathrm{Ca}^{2+}$ channel activation.

In some cells, a small (10- to 40-pA), voltage-dependent out- 
A)

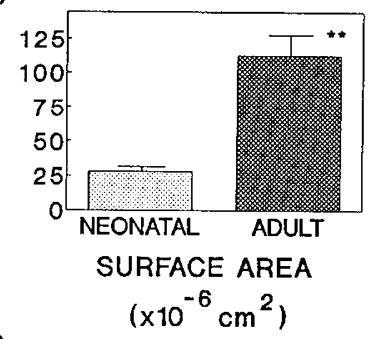

B)

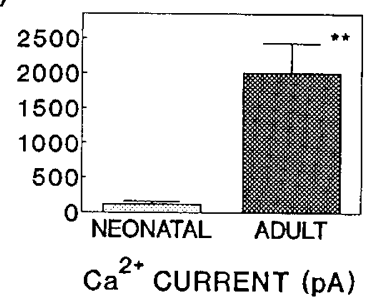

Fig. 2. Cell surface area, $\mathrm{Ca}^{2+}$ current magnitude, and $\mathrm{Ca}^{2+}$ current density in neonatal and adult myocytes. $A$, The measured 4-fold difference in cell surface area between 18 neonatal and five adult myocytes. Values represent means \pm SEM. $B$, Maximal depolarization-induced $\mathrm{Ca}^{2+}$ current in the same cells. Peak $\mathrm{Ca}^{2+}$ current is 17 -fold larger in mature cells. $C$, Maximum $\mathrm{Ca}^{2+}$ current density is shown for the same cells. This data demonstrates that the disparity between adult and neonatal peak current magnitude is a result not only of differences in cell size but also of differences in $\mathrm{Ca}^{2+}$ current density. ${ }^{* *}, p<0.001$.

\section{$\mathrm{Ca}^{2+}$ CURRENT}

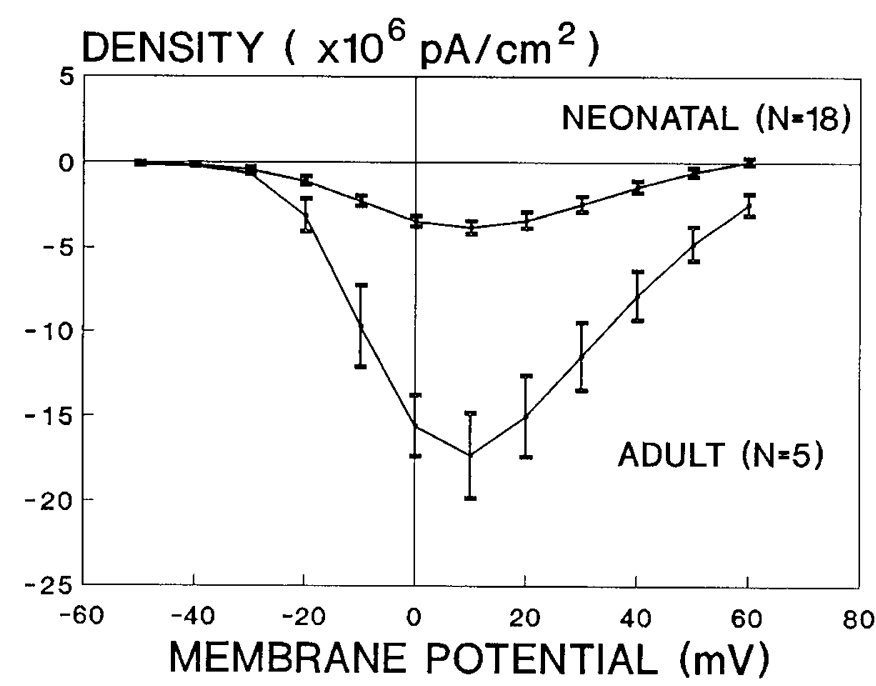

Fig. 3. Peak $\mathrm{Ca}^{2+}$ current-voltage relation for isolated neonatal and adult myocytes. Peak current density is plotted as a function of membrane test potential for depolarizations from a holding potential of -80 $\mathrm{mV}$. Values represent means $\pm \mathrm{SEM} . \mathrm{Ca}^{2+}$ channels are activated at potentials greater than $-30 \mathrm{mV}$. Peak currents become more negative (inward) as the test potential is increased to $10 \mathrm{mV}$. The shape of the curves is similar in the two age groups, indicating similar voltage dependence of steady state activation of $\mathrm{Ca}^{2+}$ channels. However, $\mathrm{Ca}^{2+}$ current density is greater in adult cells than in neonatal cells at all potentials tested.

ward current was seen by the end of a 100-ms depolarization to potentials greater than $20 \mathrm{mV}$. This current was not blocked by $100 \mu \mathrm{M} \mathrm{CdCl}_{2}$ (data not shown) and may reflect incomplete block of outward $\mathrm{K}^{+}$channel current at positive membrane potentials. This outward current may in part account for the relatively negative apparent $\mathrm{Ca}^{2+}$ reversal potential, although other explanations for a $\mathrm{Ca}^{2+}$ reversal potential between 60 and $80 \mathrm{mV}$ have been advanced (3).

T-Type $\mathrm{Ca}^{2+}$ currents. Figure $4 A$ demonstrates the presence of an early, rapidly inactivating inward current in a typical adult rabbit myocyte upon depolarization to $-20 \mathrm{mV}$ from a holding potential of $-80 \mathrm{mV}$ (trace a). This transient or T-type $\mathrm{Ca}^{2+}$ current is largely inactivated at a holding potential of $-40 \mathrm{mV}$ $($ trace $b)$. In contrast to adult myocytes, the majority of immature myocytes did not exhibit T-type currents. Figure $4 B$ shows current traces from a neonatal cell during depolarizations to -20 $\mathrm{mV}$ from holding potentials of -80 (trace a) and $-40 \mathrm{mV}$ (trace $b$ ). No early, transient current is present. Depolarizations from a holding potential of $-80 \mathrm{mV}$ to test potentials between -40 and $10 \mathrm{mV}$ in $10-\mathrm{mV}$ increments did not elicit an early transient current in these cells (data not shown).

The difference current for neonatal and adult cells is shown in Figure $4 C$. These traces reflect the component of current that is inactivated at a holding potential of $-40 \mathrm{mV}$. For adult cells, this trace clearly demonstrates a rapidly inactivating T-type current. The small, sustained difference current may reflect an incomplete steady state inactivation of L-type current at this holding potential. In neonatal myocytes no T-type current is seen.

Figure $5 A$ shows results for a cell from a 5-d-old rabbit that did exhibit a significant T-type current. Depolarization to -20 $\mathrm{mV}$ from a holding potential of $-80 \mathrm{mV}$ induced a small, transient inward current. This current was inhibited when the holding potential was changed to $-40 \mathrm{mV}$.

Treatment with neuraminidase has been shown to increase the magnitude of $T$ currents in adult guinea pig myocytes (21). This effect may be mediated through removal of sialic acid from glycosylated sarcolemmal proteins. We have studied the effect of neuraminidase on the small, transient inward current observed in some neonatal cells to provide further evidence that they in fact represent $T$ channel currents. Addition of neuraminidase might also augment a small or latent $T$-type current in cells that otherwise did not exhibit T-type current. Figure $5 B$ demonstrates the presence of T-type and L-type currents in a myocyte from a 2-d-old rabbit (induced by depolarizations to -20 and $10 \mathrm{mV}$, respectively). When neuraminidase was added to the bath solution, the magnitude of the T-type current increased (Fig. $5 C$, test potential $-20 \mathrm{mV}$ ), while the L-type current was unaffected (Fig. $5 C$, test potential $10 \mathrm{mV}$ ). However, in those neonatal cells that had no demonstrable T-type currents, latent T-type currents could not be induced by either addition of neuraminidase to the bath solution or hyperpolarization of the cell membrane to a holding potential of $-100 \mathrm{mV}$ (data not shown). T-type $\mathrm{Ca}^{2+}$ currents were present in only 20 of $51(39 \%)$ neonatal myocytes as compared with 10 of $11(91 \%)$ adult cells (Fig. 6).

The prevalence of T-type currents in neonatal cells was partially dependent on the length of time the cell was dialyzed. In 11 neonatal cells, T-type currents were apparent 5 min after cell penetration. In an additional nine cells, T-type currents became apparent within $10 \mathrm{~min}$ of cell penetration. The remaining 31 cells did not exhibit T-type currents within $20 \mathrm{~min}$ of cell penetration. There was no correlation between the observance of the T-type current and pipette series resistance.

\section{DISCUSSION}

The major finding of this study was an age-related increase in peak current density of voltage-dependent membrane $\mathrm{Ca}^{2+}$ currents. Further, T-type $\mathrm{Ca}^{2+}$ channels were found to be less prevalent in neonatal cardiac myocytes as compared with adult cells.

$\mathrm{Ca}^{2+}$ current density. In our experiments the peak $\mathrm{Ca}^{2+}$ current measured in adult myocytes was much larger than that measured in neonatal myocytes. This difference may be accounted for in part by the difference in size between the mature and immature cells. However, when normalized for surface area, current density 
A)

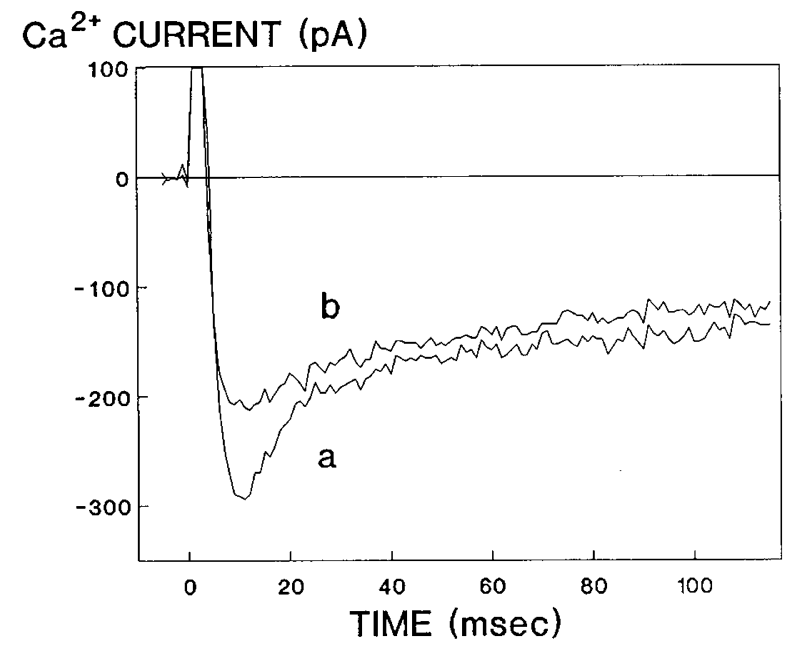

B)

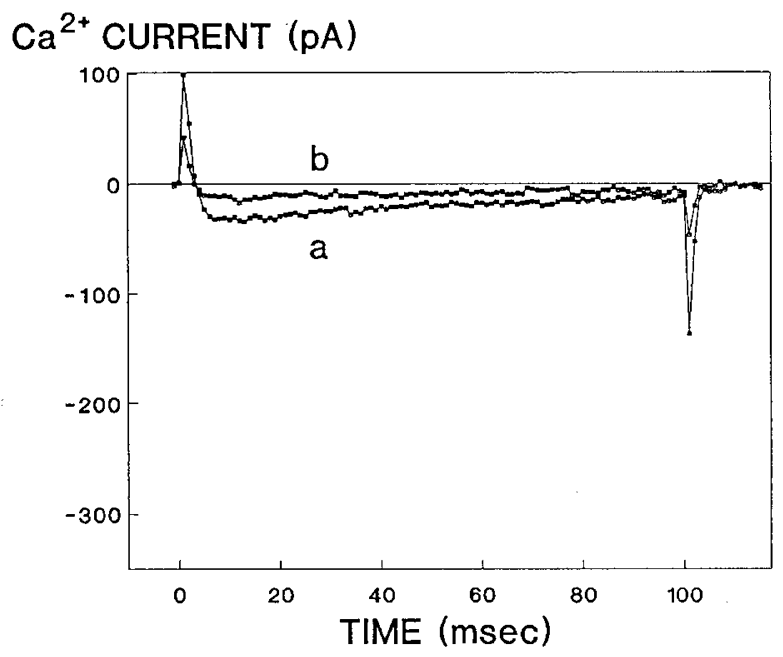

C)

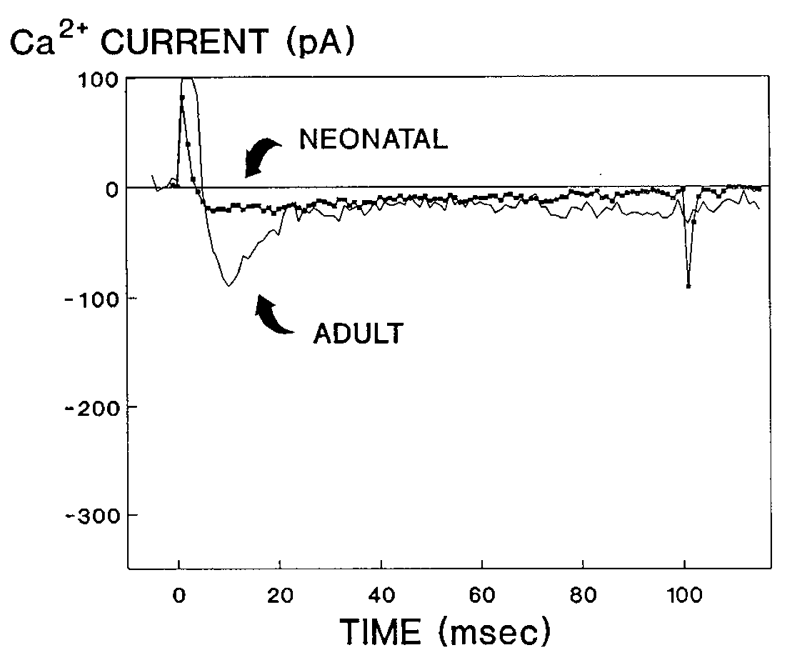

Fig. 4. T-type $\mathrm{Ca}^{2+}$ currents in adult and neonatal cells. $A$, Depolar ization of an adult cell from a holding potential of $-80 \mathrm{mV}$ to a test potential of $-20 \mathrm{mV}$ induces an early, rapidly inactivating T-type current in addition to a large, sustained L-type current (trace $a$ ). The T-type current is largely inhibited at a holding potential of $-40 \mathrm{mV}$ (trace $b$ ). Only the first $100 \mathrm{~ms}$ of a 400 -ms clamp are shown. Cell no. $90405 \mathrm{~A}$. $B$ Depolarizations of a cell from a 3-d-old rabbit from holding potentials of -80 and $-40 \mathrm{mV}$ (test potential of $-20 \mathrm{mV}$ ) induce a small, sustained in adult myocytes is significantly larger than that in neonatal cells (Fig. 3). This result is comparable to that recently reported by Osaka and Joyner (17), using a similar preparation. The smaller $\mathrm{Ca}^{2+}$ current density of neonatal cells suggests that voltage-gated $\mathrm{Ca}^{2+}$ channels may play a less significant role in the generation of the action potential in immature rabbit cells than in adult myocardium. These results contrast with the findings of Cohen and Lederer (15) that $\mathrm{Ca}^{2+}$ current density was smaller in freshly isolated adult rat myocytes than in cultured neonatal rat myocytes. The disparity in these results is not unexpected, inasmuch as the adult rat myocyte action potential displays an attenuated plateau phase suggestive of a decreased role for $\mathrm{Ca}^{2+}$ currents in adult rat myocardium. However, other species-specific differences, differences between cultured and freshly isolated cells, and differences in cell morphology may also contribute to this discrepancy.

Measurement of cell surface area. As a qualitative check on the capacitance measurements reported in this investigation, we have calculated cell surface area from planar cell size. Using reported values of mean cell length and diameter (11) and assuming the cells to be roughly cylindrical, the cell surface area of 3-wk-old and adult rabbit myocytes can be calculated as approximately 40 and $100 \times 10^{-6} \mathrm{~cm}^{2}$, respectively. These values are in reasonable agreement with the 4-fold increase in cell membrane areas $\left(28\right.$ and $\left.113 \times 10^{-6} \mathrm{~cm}^{2}\right)$ for neonatal and adult rabbits calculated from capacitance measurements in this study.

Intracellular $\mathrm{Ca}^{2+}$ concentration. Besides contributing to the plateau of the action potential, $\mathrm{Ca}^{2+}$ currents may also play a role in delivering $\mathrm{Ca}^{2+}$ to the myoplasm and myofibrils. The effectiveness of current crossing the membrane in increasing intracellular $\mathrm{Ca}^{2+}$ concentration depends not only on the current density but also on the volume of the cell. Although neonatal rabbit myocytes have a smaller current density than mature cells, their surface area to volume ratio is larger. The precise magnitude of this difference is dependent on the shape of the cells. However, assuming the cells to be right cylinders, an 8 -fold increase in cell volume would be expected for the observed 4-fold increase in surface area. Thus, the measured 17 -fold difference in peak $\mathrm{Ca}^{2+}$ current would be expected to increase intracellular $\mathrm{Ca}^{2+}$ concentration twice as much in adult cells as in neonatal cells. This calculation is an approximation and does not take into account differences in $\mathrm{Ca}^{2+}$ volumes of distribution, localized concentration gradients, or intracellular $\mathrm{Ca}^{2+}$ binding and sequestration. However, these data do suggest that the rise in intracellular $\mathrm{Ca}^{2+}$ attributable to the voltage-gated $\mathrm{Ca}^{2+}$ channels in neonatal cells may be smaller than in adult cells.

In adult myocardium, tension generation depends upon $\mathrm{Ca}^{2+}$ release from the sarcoplasmic reticulum to supplement transsarcolemmal $\mathrm{Ca}^{2+}$ influx (which provides only about $5-15 \%$ of the intracellular $\mathrm{Ca}^{2+}$ transient)(1). The previous calculation suggests that the rise in intracellular $\mathrm{Ca}^{2+}$ attributable to $\mathrm{Ca}^{2+}$ influx via L-type channels may be even smaller in the neonate than in the adult. Thus, voltage-gated $\mathrm{Ca}^{2+}$ channels may not play a central role in raising the intracellular $\mathrm{Ca}^{2+}$ concentrations in immature myocardium.

T-type $\mathrm{Ca}^{2+}$ currents. The present work demonstrates the existence of small, transient inward currents in neonatal myo-

L-type current (traces $a$ and $b$, respectively). In contrast to the adult cell in $A$, however, no T-type current is present. The clamp duration is 100 ms. Cell no. 89 N29D. $C$, The difference current for depolarizations to $-20 \mathrm{mV}$ from holding potentials of -80 and $-40 \mathrm{mV}$ is calculated by performing a point-by-point subtraction of traces $a$ and $b$ for both the neonate and adult. The difference current for the adult cell illustrates the rapidly inactivating T-type current (which is inactivated at a holding potential of $-40 \mathrm{mV}$ ) as well as a small, sustained component resulting for incomplete steady state inactivation of L-type current at $-40 \mathrm{mV}$. The difference current of the neonatal cell has no rapidly inactivating or T-type current component but only a slowly inactivating component consistent with incomplete inactivation of the L-type current at $-40 \mathrm{mV}$. 
A)
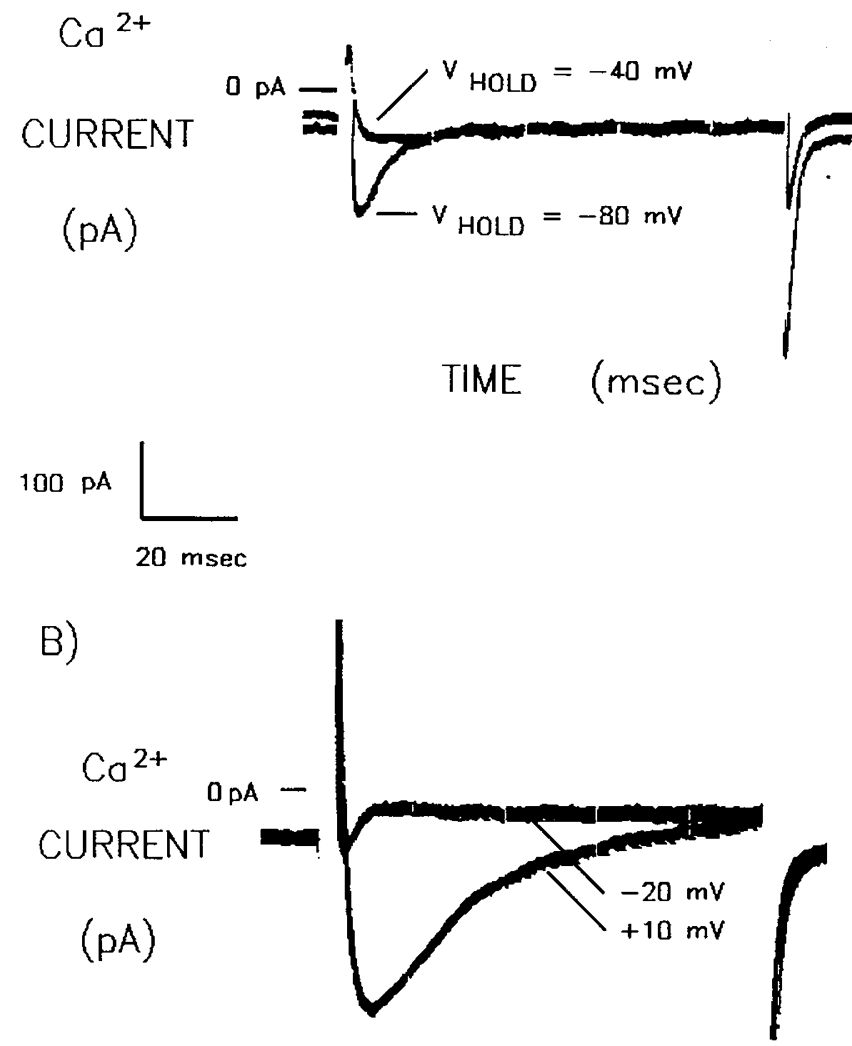

$100 \mathrm{pA} \underbrace{\bigsqcup_{(}}_{20 \mathrm{msec}}$

c)

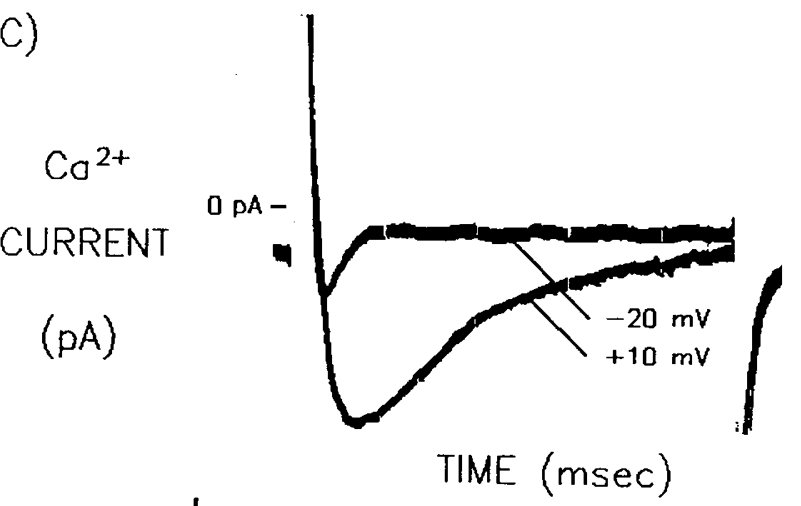

$100 \mathrm{pA}$

TIME (msec)

TIME (msec)

20 msec

Fig. 5. T-type channels in neonatal myocytes: the effect of neuraminidase. $A$, Depolarization from -80 to $-20 \mathrm{mV}$ induces a prominent, transient, early (T-type) current and a smaller, sustained (L-type) current in this cell from a 5-d-old rabbit. When the holding potential is changed to $-40 \mathrm{mV}$, the $\mathrm{T}$ current component is inactivated but the $\mathrm{L}$ current component is unchanged (cell no. 148, clamp duration $100 \mathrm{~ms}$ ). Compare these traces with those of Figure $4 B$, where no T-type current is present. $B$, Current recordings from a cell from a 2-d-old rabbit are shown for 100 -ms depolarizations from a holding potential of $-80 \mathrm{mV}$ to test potentials of -20 and $10 \mathrm{mV}$. Transient $\mathrm{T}$ and sustained $\mathrm{L}$ current activity are induced by depolarizations to -20 and $10 \mathrm{mV}$, respectively. Cell no. 278. $C$, Neuraminidase has been shown to potentiate T channel cytes that are activated by voltage clamp steps from -80 to -20 $\mathrm{mV}$ and are not present during steps from a holding potential of -40 to $-20 \mathrm{mV}$ (Fig. 5 and 6). These currents are selectively increased in the presence of neuraminidase, lending support to the hypothesis that they represent current passing through neonatal T-type channels. Thus, glycosylation of sarcolemmal proteins may play a role in regulating $T$ channel activity in immature myocardium as has been suggested in adult tissue (21).

The lower prevalence of T-type channels in neonatal cells as compared with adult cells has not been previously reported. Tseng and Boyden (22) have reported an increased prevalence of $\mathrm{T}$ currents in canine Purkinje cells as compared to cells isolated from the left ventricular free wall. They also note that $\mathrm{L}$ current density was smaller in the Purkinje cells. In our experiments cells were isolated from the entire, intact ventricle, and the isolation procedure was similar in both age groups. However, the possibility that the isolation procedure increases the yield of a regional pool of neonatal myocytes deficient in $\mathrm{Ca}^{2+}$ channels or selectively inhibits $\mathrm{Ca}^{2+}$ channel activity cannot be excluded.

The role that $\mathrm{T}$ channels play in the physiology of mature myocardium is not known and, therefore, the mechanistic significance of the relative paucity of T-type current in immature cells is not clear. It has been proposed that $\mathrm{T}$ channels may play a role in the stimulation of $\mathrm{Ca}^{2+}$-dependent $\mathrm{Ca}^{2+}$ release from the sarcoplasmic reticulum in adult cells (5). The relative absence of sarcoplasmic reticulum and $\mathrm{T}$ tubules in neonatal myocytes taken together with the relative lack of T-type channels in neonatal cells is consistent with this hypothesis. However, further investigation into a possible relationship between $T$ currents and release of $\mathrm{Ca}^{2+}$ from the sarcoplasmic reticulum is clearly necessary.

Influence of $\mathrm{Ca}^{2+}$ current rundown. Rundown, an irreversible fall in $\mathrm{Ca}^{2+}$ conductance in dialyzed cells or isolated membrane patches, is a well-known phenomenon of sarcolemmal $\mathrm{Ca}^{2+}$ channels and may be related to dephosphorylation of membrane proteins. Rundown in mature guinea pig myocytes occurs at a constant rate over the first 10 to 40 min after cell penetration and then accelerates (23). We have found that $\mathrm{Ca}^{2+}$ current in neonatal cells initially decreases linearly with time with a halftime of approximately $20 \mathrm{~min}(16)$.

We have recorded peak $\mathrm{Ca}^{2+}$ currents after 5 min of cell dialysis. At that time the ionic composition of the interior of the cell would have largely equilibrated with the pipette solution (16). Because $\mathrm{Ca}^{2+}$ current is predicted to have run down by only about $10 \%$ during that time, our results cannot be explained by an acceleration of the rundown of $\mathrm{Ca}^{2+}$ current in neonatal cells. Similarly, rapid, selective inhibition of T-type current was not observed. In fact $\mathrm{T}$-type currents generally became more prominent with rundown of the L-type current.

Developmental significance. We have shown that peak $\mathrm{Ca}^{2+}$ current density in rabbit cardiac myocytes increases with age, similar to the maturational changes described for other subcellular cardiac structures, such as mitochondria, sarcoplasmic reticulum, myofibrils, $\mathrm{T}$ tubules, and contractile proteins $(2,9-$ 12). The finding that $\mathrm{Ca}^{2+}$ current densities are larger in adult as compared with neonatal heart cells may reflect an increase in $\mathrm{Ca}^{2+}$ channel production in more mature cells. Alternatively, single-channel $\mathrm{Ca}^{2+}$ conductance or open-state probability may

currents in adult cardiac myocytes. This panel illustrates the effect of neuraminidase $(0.125 \mathrm{U} / \mathrm{mL})$ on the early transient current in neonatal cells (same cell and voltage protocol as in $B$ ). Neuraminidase increased the magnitude of the T-type current (depolarization to $-20 \mathrm{mV}$ ) without significantly affecting L-type $\mathrm{Ca}^{2+}$ current (depolarization to $10 \mathrm{mV}$ ). In neonatal cells displaying $\mathrm{T}$-type $\mathrm{Ca}^{2+}$ currents, neuraminidase increased the magnitude of the peak current $(57 \pm 9$ vs $72 \pm 10 \mathrm{pA}$, mean \pm SEM, $n=6, p<0.001$ ). However, neuraminidase failed to induce T-type $\mathrm{Ca}^{2+}$ currents in neonatal cells in which they were previously absent $(n=7)$. In this figure, leak currents have not been subtracted. 
T CHANNEL PREVALENCE

\section{T CHANNELS ABSENT} T CHANNELS PRESENT

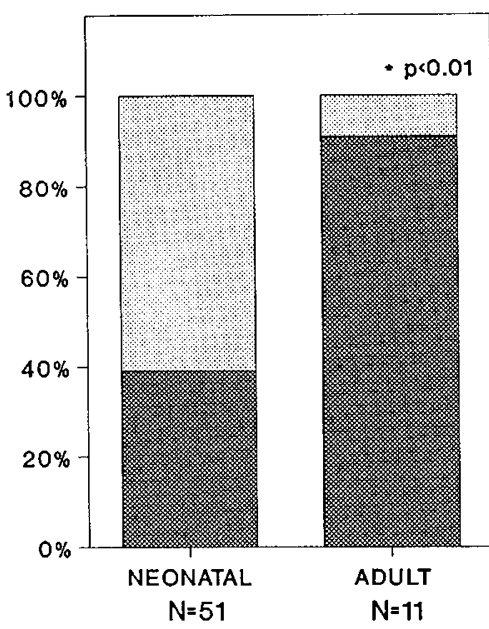

Fig. 6. Prevalence of T-type channels in isolated myocytes. The percentage of cells with demonstrable T-type currents is depicted for both neonatal and adult cells. The prevalence of $T$ currents in adult cells is significantly greater as compared with neonatal cells (means \pm SEM, $*, p<0.01$ by $\chi^{2}$ analysis).

increase with development, suggesting changes in actual channel structure or regulation.

The lower current density of L-type $\mathrm{Ca}^{2+}$ channels in immature myocytes and the lower prevalence of $\mathrm{T}$-type $\mathrm{Ca}^{2+}$ currents suggest that sarcolemmal $\mathrm{Ca}^{2+}$ channels may have a less significant role in intracellular $\mathrm{Ca}^{2+}$ regulation in immature than in mature cardiac myocytes. This conclusion is in apparent contradiction to the crucial role of extracellular $\mathrm{Ca}^{2+}$ in supporting tension generation in immature myocardium as demonstrated in previous studies $(2,8-13)$. Thus, an additional mechanism of transsarcolemmal $\mathrm{Ca}^{2+}$ movement into the cell (for example $\mathrm{Na}^{+}-\mathrm{Ca}^{2+}$ exchange) may play a significant role in tension generation in immature myocardium.

Acknowledgments. The authors thank Mathilde Mazoumian for her assistance in the isolation of neonatal myocytes and Sarah Warren for her help in the preparation of this manuscript.

\section{REFERENCES}

1. Cavalie A, Ochi R, Pelzer D, Trautwein W 1983 Elementary currents through $\mathrm{Ca}^{2+}$ channels in guinea pig myocytes. Pflugers Arch 398:284-297

2. Klitzner T, Friedman WF 1988 Excitation-contraction coupling in developing mammalian myocardium: evidence from voltage clamp studies. Pediatr Res 23:428-432

3. Lee KS, Tsien RW 1982 Reversal of current through calcium channels in dialyzed single heart cells. Nature 297:498-501

4. Mitra R, Morad M 1986 Two types of calcium channels in guinea pig ventricular myocytes. Proc Natl Acad Sci USA 63:5340-5344

5. Morad M. Cleemann L 1987 Role of $\mathrm{Ca}^{2+}$ channel in development of tension in heart muscle. J Mol Cell Cardiol 19:527-553

6. Nilius B, Hess P, Lansman JB, Tsien RW 1985 A novel type of cardiac calcium channel in ventricular cells. Nature 316:443-446

7. Chapman RA 1983 Control of cardiac contractility at the cellular level. Am J Physiol 245:H535-H552

8. Jarmakani JM, Nakanishi T, George BL, Bers D 1982 Effect of extracellular calcium on myocardial mechanical function in the neonatal rabbit. Dev Pharmacol Ther 5:1-13

9. Mahony L, Jones LR 1986 Developmental changes in cardiac sarcoplasmic reticulum in sheep. $\mathrm{J}$ Biol Chem 261:15257-15265

10. Maylie JG 1982 Excitation-contraction coupling in neonatal and adult myocardium of cat. Am J Physiol 284:H834-H843

11. Nassar R, Reedy MC, Anderson PAW 1987 Developmental changes in the ultrastructure and sarcomere shortening of the isolated rabbit ventricular myocyte. Circ Res 61:465-483

12. Page E, Buecker JL 1981 Development of dyadic junctional complexes between sarcoplasmic reticulum and plasmalemma in rabbit left ventricular myocardial cells: morphometric analysis. Circ Res 48:519-522

13. Chin TK, Friedman WF, Klitzner TS 1990 Developmental changes in cardiac myocyte calcium regulation. Circ Res 67:574-579

14. Reuter H, Stevens CF, Tsien RW, Yellen G 1982 Properties of single calcium channels in cardiac cell culture. Nature 297:501-504

15. Cohen NM, Lederer WJ 1988 Changes in the calcium current of rat heart ventricular myocytes during development. J Physiol (London) 406:115-146

16. Wetzel GT, Chen F, Friedman WF, Klitzner TS 1991 Calcium current measurements in acutely isolated neonatal cardiac myocytes. Pediatr Res 30:8388

17. Osaka T, Joyner RW 1991 Developmental changes in calcium currents in rabbit ventricular cells. Circ Res 68:788-796

18. Hamill OP, Neher ME, Sakmann B, Sigworth FJ 1981 Improved patch-clamp techniques for high-resolution current recording from cells and cell-free membrane patches. Pflugers Arch 391:85-100

19. Pusch M, Neher E 1988 Rates of diffusional exchange between small cells and a measuring patch pipette. Pflugers Arch 411:204-211

20. Marty A, Neher E 1983 Tight-seal whole-cell recording. In: Sakmann B, Neher E (eds) Single-Channel Recording. Plenum Press, New York, pp 107-122

21. Yee HF, Weiss JN, Langer GA 1989 Neuraminidase selectively enhances transient $\mathrm{Ca}^{2+}$ current in cardiac myocytes. Am J Physiol 256:C1267-C1272

22. Tseng GN, Boyden PA 1989 Multiple types of $\mathrm{Ca}^{2+}$ currents in single canine purkinje cells. Circ Res 65:1735-1750

23. Belles B, Malécot CO, Hescheler J, Trautwein W 1988 "Run-down" of the Ca current during long whole-cell recordings in guinea pig heart cells: role of phosphorylation and intracellular calcium. Pflugers Arch 411:353-360 